\title{
Cut-off Values of Bacteriuria and Leukocyturia for the Diagnosis of Urinary Tract Infections in Pediatric Patients
}

\author{
Muhamad Ramdani Ibnu Taufik ${ }^{1}$, Dian Ariningrum², Yusuf Ari Mashuri ${ }^{3}$ \\ ${ }^{1}$ Department of Medicine, Faculty of Medicine, Sebelas Maret University, Surakarta, Indonesia. E-mail: dianariningrum@staff.uns.ac.id \\ ${ }^{2}$ Department of Clinical Pathology, Faculty of Medicine, Sebelas Maret University/Dr. Moewardi Hospital, Surakarta, Indonesia \\ ${ }^{3}$ Laboratory of Parasitology, Faculty of Medicine, Sebelas Maret University, Surakarta, Indonesia
}

\begin{abstract}
The diagnosis of Urinary Tract Infection (UTI) in infants and children is often missed. There have been no studies on diagnostic tests using automated urine analyzer in pediatric patients. This study aimed to determine the cut-off values of bacteriuria and leukocyturia using the automated urine analyzer Sysmex UX-2000 to diagnose UTI with the gold standard of automated urine culture using VITEK 2 in pediatric patients at Dr. Moewardi Hospital, Surakarta. An observational analytical study with the cross-sectional design was during August-October 2019 at the Clinical Pathology Laboratory and Clinical Microbiology Laboratory of Moewardi Hospital, Surakarta. Eighty-four patients sample were collected. This study's dependent variable was the diagnosis of urinary tract infections in pediatric patients established with positive culture results (bacterial count of $\geq 105 \mathrm{CFU} / \mathrm{mL}$ urine). This study's independent variables were the number of urine bacteria (BACT) and the number of urine leukocytes (WBC) from urinalysis using the Sysmex UX-2000 automated urine analyzer. A diagnostic test was used for data analysis. The best cut-off value for leukocyturia was 37 cells $/ \mu \mathrm{L}$ with a $61.1 \%$ sensitivity, $63.6 \%$ specificity, a positive predictive value of $31.4 \%$; a negative predictive value of 85.7 ; positive likelihood ratio of 1.64 ; negative likelihood ratio of 0.595 , and accuracy of $63 \%$. The best cut-off for the number of bacteria was 143 cells/ $\mu \mathrm{L}$ with a sensitivity of $66.7 \%$; specificity of $71.2 \%$, the positive predictive value of $38.7 \%$, the negative predictive value of $88.7 \%$; positive likelihood ratio of 2.14; negative likelihood ratio of 0.432 and an accuracy of $70.2 \%$. A cut-off of 37 cells/ $\mu \mathrm{L}$ for leukocyturia and 143 cells/ $\mu \mathrm{L}$ for bacteriuria using an automated urine analyzer can be used for UTI screening in pediatric patients.
\end{abstract}

Keywords: Urinary tract infections, children, leukocyturia, bacteriuria, Sysmex UX-2000

\section{INTRODUCTION}

Urinary Tract Infections (UTI) are among the most dominant infectious diseases and have an essential financial burden in the community. The incidence of urinary tract infections in children varies greatly depending on age and gender. UTI's risk in the first decade after males' birth is $1 \%$, and females are $3 \%$. At least $5 \%$ of girls and $0.5 \%$ of school-age boys experience one episode of UTI. Urinary tract infection was more commonly found in Male babies less than three months old compared to female babies. ${ }^{1}$

The diagnosis of UTI in infants and children at primary health care is often missed. This fact is due to the lack of awareness and limited facilities to rule out UTI. Symptoms of UTI in children tend to be less specific. The diagnosis process, which requires quite a long time and expensive costs, is another obstacle in diagnosing UTI. ${ }^{2}$ Clinical symptoms of UTI in children are usually mild and non-specific, and fever is often the only symptom. Hypothermia, lethargy, irritability, decreased appetite, vomiting, diarrhea, jaundice, failure to thrive, sepsis, or foul-smelling urine are other symptoms that may be found. ${ }^{2.3}$

There has been no study about bacteriuria and leukocyturia's diagnostic performance using an automated urine analyzer in pediatric patients. The definitive diagnosis of UTI is considered very important to provide appropriate treatment to patients. The gold standard is still considered costly and requires a long time of processing. In this study, researchers compared the detection of bacteria and leukocytes using the Sysmex UX-2000 to the gold standard, urine culture, particular attention to cut-off values for bacteriuria leukocyturia, to carry out a fast and reliable diagnosis of UTI. ${ }^{4}$

\section{METHODS}

This study was a diagnostic test using a cross-sectional design and urine culture as the gold standard. This research was performed at the Clinical Pathology Laboratory and Microbiology Laboratory of Dr. Moewardi Hospital, Surakarta. The inclusion 
criteria were pediatric patients with clinical suspicion of UTI, aged 1-18, who came to the Pediatric Outpatient Clinic or were treated in the Pediatric Ward at Dr. Moewardi Hospital between October 2018 and October 2019. Urine culture was done using VITEK 2, and automated urinalysis using Sysmex UX-2000. The informed consent was taken from all subjects. Exclusion criteria were patients with an incomplete test. Clinical data were taken from the patient's medical record. The culture results were obtained from the register of VITEK 2 from the Microbiology Laboratory. The number of bacteria (BACT) and the number of leukocytes (WBC) were obtained from the record of Sysmex UX-2000 automated urine analyzer from the Clinical Pathology Laboratory. The Receiver Operating Characteristics (ROC) curves for WBC and BACT were plotted, sensitivity (SE), specificity (SP), Positive Predictive Value (PPV), Negative Predictive Value $(N P V)$, likelihood ratios, and accuracy were then evaluated. The data were analyzed using STATA version 14.2.

Research permission was obtained from the Health Research Ethics Committee of the Dr. Moewardi General Hospital with number 883/VII/HREC/2019.

\section{RESULTS AND DISCUSSION}

The subjects' characteristics, including age, gender, comorbidities, and urine sources, can be seen in Table 1. The number of subjects in this study were 84 , consisting of 55 hospitalized subjects (65.5\%) and 29 subjects (34.5\%) with Outpatients care. The number of samples from female subjects was equal to male subjects. There were 18 samples
(21.4\%) with positive culture (i.e. bacterial count of $>105 \mathrm{CFU} / \mathrm{mL}$ ) and 66 samples (78.6\%) with negative culture (i.e. no growth or bacterial count of $<105$ $\mathrm{CFU} / \mathrm{mL}$ ). Among samples with positive culture result, seven samples (38.9\%) were Klebsiella pneumoniae, four samples (22.2\%) were Escherichia coli, two samples (11.1\%) were Pseudomonas aeruginosa, three samples were Gram-positive cocci (Staphylococcus aureus, Streptococcus haemolyticus, and Enterococcus faecalis), 2 other samples were Stenotrophomonas maltophillia and Salmonella $s p$.

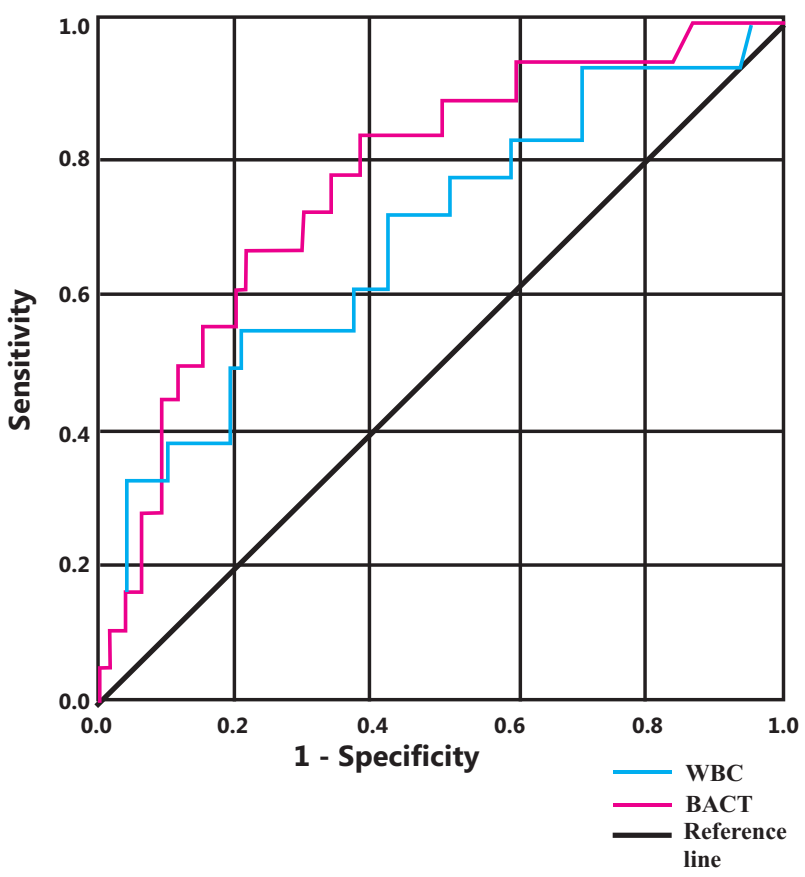

Figure 1. Receiver operating characteristics curve of $\mathrm{WBC}$ and $\mathrm{BACT}$ to diagnose urinary tract infection

Table 1. Characteristics of research subjects

\begin{tabular}{lcccccc}
\hline \multirow{2}{*}{ Characteristics } & \multicolumn{3}{c}{ Culture (+) } & \multicolumn{2}{c}{ Culture (-) } & \multicolumn{2}{c}{ Total } \\
\cline { 2 - 7 } & $\mathbf{n}$ & $\%$ & $\mathbf{n}$ & $\%$ & $\mathbf{n}$ & $\%$ \\
\hline Age (year) & 6 & 23.1 & 20 & 76.9 & 26 & 30.85 \\
$1-5$ & 12 & 20.7 & 46 & 79.3 & 58 & 69.05 \\
6-18 & & & & & & \\
Gender & 11 & 26.2 & 31 & 73.8 & 42 & 50 \\
$\quad$ Female & 7 & 16.7 & 35 & 83.3 & 42 & 50 \\
$\quad$ Male & & & & & & \\
Comorbidities & 4 & 13.3 & 26 & 86.7 & 30 & 35.7 \\
$\quad$ Malignancy & 14 & 25.9 & 40 & 74.1 & 54 & 64.3 \\
$\quad$ Non-malignancy & & & & & & \\
Source of urine & 16 & 20.8 & 61 & 79.2 & 77 & 91.7 \\
$\quad$ Mid-stream & 2 & 28.6 & 5 & 71.4 & 7 & 8.3 \\
$\quad$ Catheterized & & & & & & \\
\hline
\end{tabular}


From the ROC curve (Figure 1), the Area Under Curve (AUC) of WBC and BACT was 0.701 (95\%CI 0.559-0.843) and 0.779 (95\%CI 0.658-0.899), respectively. The AUC of BACT had a higher value than the AUC of WBC $(p=0.009)$.

Tables 2 and 3 showed the sensitivities and specificities of various cut-off values for WBC and BACT. As shown in Tables 2 and 4, the best cut-off value for WBC was 37 cells/ $\mu \mathrm{L}$ with a sensitivity of $61.1 \%$ and a specificity of $63.6 \%$. This cut-off also gave a PPV of $31.4 \%$, a NPV of $85.7 \%$, a positive likelihood ratio of 1.64 , and an accuracy of $63 \%$. Table 3 and 4 also showed the best cut-off value of 143 cells $/ \mu \mathrm{L}$ for BACT with a sensitivity of $66.7 \%$; specificity of $71.2 \%$; a positive predictive value of $38.7 \%$; a negative predictive value of $88.7 \%$; positive likelihood ratio of 2.14 ; and an accuracy of $70.2 \%$.

In contrast to this study, Pratistha reported a higher cut-off of 52.8 cells/ $\mu \mathrm{L}$ for leukocyturia with a sensitivity of $82.3 \%$, a specificity of $76.3 \%$, PPV of

Table 2. Sensitivity and specificity for WBC at various cut-off values

\begin{tabular}{lccc}
\hline & \multicolumn{3}{c}{ Cut-off Value for WBC (cells/ $\boldsymbol{\mu L}$ ) } \\
\cline { 2 - 4 } & 35.3 & 35.8 & 37 \\
\hline Sensitivity & $61.1 \%$ & $61.1 \%$ & $61.1 \%$ \\
Specificity & $59.1 \%$ & $62.1 \%$ & $63.6 \%$ \\
\hline
\end{tabular}

Table 3. Sensitivity and specificity for BACT at various cut-off values

\begin{tabular}{lccc}
\hline & \multicolumn{3}{c}{ Cut-off Value for BACT (cells/ $\boldsymbol{\mu L}$ ) } \\
\cline { 2 - 4 } & 99.35 & 112.4 & 143 \\
\hline Sensitivity & $72.2 \%$ & $66.7 \%$ & $66.7 \%$ \\
Specificity & $69.7 \%$ & $69.7 \%$ & $71.2 \%$ \\
\hline
\end{tabular}

$85 \%$, NPV of $72.5 \%$, and accuracy of $84.6 \%{ }^{5}$ Similar research by Bargotya et al. reported a lower cut-off value of 19.8 cells $/ \mu \mathrm{L}$ with a sensitivity of $82.3 \%$, a specificity of $80.9 \%$, PPV of $54.3 \%$, and NPV of 93.5\% ${ }^{6}$ Giesen et al. reported that the flow cytometry method resulted in a lower cut-off of leukocyturia $(\geq 31.8$ cells $/ \mu \mathrm{L}$ ) with a sensitivity of $89 \%$, a specificity of $79 \%$, PPV of $38 \%$, and NPV of $98 \%$. $^{7}$ Agpaoa et al. obtained cut-off of $\geq 27$ cells/ $\mu \mathrm{L}$ for leukocyturia, with a sensitivity of $84.6 \%$; specificity of $65.4 \%$; PPV of $71 \%$ and NPV of $81 \%$. The cut-off value for WBC obtained in this study was similar to that of Agpaoa et al. ${ }^{8}$

The best cut-off for the bacterial count (BACT) for the diagnosis of UTI was 143 cells $/ \mu \mathrm{L}$ with a sensitivity of $66.7 \%$, a specificity of $71.2 \%$; PPV of $38.7 \%$; NPV of $88.7 \%$; positive likelihood ratio LR of 2.14 , and accuracy of $70.2 \%$. Bargotya et al. determined a higher cut-off of 198.8 cells/ $\mu \mathrm{L}$ with a sensitivity of $82.1 \%$, a specificity of $79.5 \%$, a PPV of $54.3 \%$, and NPV of $92.7 \%{ }^{6}$

Variations in the cut-off values of leukocyturia and bacteriuria can be caused by differences in study populations, characteristics of study samples in inclusion criteria, and differences in the interpretation of positive urine cultures. ${ }^{5}$ The high NPV values of leukocyturia and bacteriuria in this study indicated these two parameters' ability to predict negative urine culture results of $85.7 \%$ and $88.7 \%$, respectively, to exclude UTI diagnosis. Based on the study results, it could be concluded that the cut-off value of 37 cells $/ \mu \mathrm{L}$ for WBC and 143 cells $/ \mu \mathrm{L}$ for bacteriuria (BACT) can be used for UTI screening in pediatric patients.

This study was the first research that determined the cut-off value of bacteriuria and leukocyturia in

Table 4. Sensitivity, specificity, PPV, NPV, accuracy, and likelihood ratios for WBC at a cut-off of 37 cells/ $\mu$ L and BACT at a cut-off of 143 cells $/ \mu \mathrm{L}$

\begin{tabular}{lcc}
\hline & $\begin{array}{c}\text { WBC at Cut-off } \mathbf{3 7} \\
\text { cells/ } \mathbf{\mu L}\end{array}$ & $\begin{array}{c}\text { BACT at Cut-off } \mathbf{1 4 3} \\
\text { cells/ } \boldsymbol{\mu L}\end{array}$ \\
\hline Sensitivity $(95 \% \mathrm{CI})$ & $61.1 \%$ & $66.7 \%$ \\
& $(35.7 \%-82.7 \%)$ & $(41 \%-86.7 \%)$ \\
Specificity $(95 \% \mathrm{CI})$ & $63.6 \%$ & $71.2 \%$ \\
& $(50.9 \%-75.1 \%)$ & $(58.7 \%-81.7 \%)$ \\
PPV (95\% CI) & $31.4 \%$ & $38.7 \%$ \\
& $(16.9 \%-49.3 \%)$ & $(21.8 \%-57.8 \%)$ \\
NPV (95\% CI) & $85.7 \%$ & $88.7 \%$ \\
& $(72.8 \%-94.1 \%)$ & $(77 \%-95.7 \%)$ \\
Positive likelihood ratio (95\% CI) & 1.64 & 2.14 \\
& $(0.892-3)$ & $(1.09-4.18)$ \\
Accuracy & $63 \%$ & $70.2 \%$ \\
\hline
\end{tabular}


pediatric patients aged 1-18 years using automated urinalyzer Sysmex UX-2000. As a retrospective study, this study had several limitations, such as no proper control of urine sampling procedures for urinalysis and urine culture and no consideration of the history of antibiotics prescribed to patients, which increased false-negative results of urine cultures.

\section{CONCLUSION AND SUGGESTION}

The best cut-off leukocyturia for UTI diagnosis was 37 cells $/ \mu \mathrm{L}$ with a sensitivity of $61.1 \%$; specificity of $63.6 \%$; PPV of $31.4 \%$; NPV of $85.7 \%$; positive likelihood ratio of 1.64 ; and accuracy of $63 \%$. The best cut-off for bacteriuria 143 cells/ $\mu \mathrm{L}$ with a sensitivity of $66.7 \%$; specificity of $71.2 \%$; PPV of 38.7\%; NPV of $88.7 \%$; positive likelihood ratio of 2.14; and an accuracy of $70.2 \%$. This study's cut-off values can be used to rule out a UTI diagnosis in pediatric patients due to the high negative predictive value obtained, which was $85.7 \%$ for bacteriuria and $88.7 \%$ for leukocyturia. Further research using a prospective research design and consideration of antibiotics prescribed to patients as needed.

\section{REFERENCES}

1. Seputra KP, Tarmono Bambang SN, Chaidir AM, Irfan W, Johan R, DKK. Guideline penatalaksanaan infeksi saluran kemih dan genitalia pria 2015. Jakarta, Ikatan Ahli Urologi Indonesia, 2015; 44-57.

2. Musim. Enhanced urinalysis dengan urin mid-stream sebagai uji diagnostik infeksi saluran kemih pada anak [Tesis]. Yogyakarta, Program Pasca Sarjana Universitas Gadjah Mada, 2007; 1-80.

3. Sutanto K. Validitas dan cut-off bakteri urine berdasarkan metode flow cytometry untuk mendiagnosis infeksi bakteri saluran kemih [Tesis]. Surakarta, Program Pendidikan Dokter Spesialis Patologi Klinik Universitas Sebelas Maret, 2012; 1-70.

4. Sysmex Corporation. Fully automated integrated urine analyzer UX-2000 Instructions for Use. Japan, Kobe, 2011; 315-344.

5. Pratistha FSM, Sudhana IW, Adnyana IWL. Diagnosis cepat infeksi saluran kemih dengan menghitung jumlah leukosituria pada urinalisis metode flow cytometry Sysmex UX-2000 dengan baku emas kultur urin di RSUP Sanglah Denpasar. E-Jurnal Medika Udayana, 2018; 7(5): 211-216.

6. Bargotya M, Kumar L, Das P, Kachhap P, Sachdeva V, Monika K. Evaluation of advantages of multiple parameters of an automated urine analyzer in clinical practice. Ann Clin Cytol Pathol, 2018; 4(5): 1110.

7. Giesen C, Greeno A, Thompson K. Performance of flow cytometry to screen urine for bacteria and white blood cell prior to urine culture. Clin Biochem, 2013; 4(2): 68-72.

8. Agpaoa VV, Mendoza JB, Fernandez AJM, Veloso JD, Bhatnagar S. Predict urinary tract infection and to estimate causative bacterial class in a Philippine subspecialty hospital. Journal of Nephrology \& Therapeutics, 2015; 194: 1-2. 